\title{
ANALISIS PENJUALAN EMAS DAN PENERAPAN MODEL ESTIMASI YANG EFEKTIF PADA PT ANEKA TAMBANG
}

\author{
Oleh: \\ Fatima Tuzzahara Alkaf ${ }^{1}$ \\ Dharma Putra ${ }^{2}$ \\ Soebagyo ${ }^{3}$ \\ Dosen Program Studi Manajemen, Fakultas Ekonomi dan Bisnis \\ Universitas Pancasila, Jakarta \\ Email: fatimatuzzahara@univpancasila.ac.id ${ }^{1}$
}

\begin{abstract}
ABSTRAK
Analisis Penjualan Emas dan Penerapan Model Estimasi Yang Efektif Pada PT. Aneka Tambang (ANTAM) selama periode 2012Q1-2016Q4. Tujuan penelitian ini adalah untuk mengidentifikasi model-model alat analisis statistik yang digunakan sebagai alat prediksi paling efektif. Pengumpulan data dilakukan melalui pengumpulan data sekunder yang diperoleh dari laporan kuartalan PT. Aneka Tambang (ANTAM) Tbk. Analisis dilakukan dengan menerapkan enam model estimasi. Dari enam model tersebut menunjukkan bahwa estimasi model semi average dalam hal ini relatif lebih efektif dibanding model-model lainnya dalam meramalkan volume penjualan emas ANTAM.
\end{abstract}

Kata Kunci: Emas, Penjualan, Ramalan

\section{A. PENDAHULUAN}

Pertumbuhan ekonomi suatu negara sangat mempengaruhi peningkatan investasi di negara tersebut. Investasi merupakan salah satu bentuk nyata dari motif seseorang, investor ataupun organisasi saat memegang dana tunai (Jain, 2007). Mulai dari masyarakat kecil sampai atas, investasi mulai banyak digemari karena investasi dapat menjadi pemasukan tambahan bagi para investor. Selain saham, emas merupakan investasi yang cukup menjanjikan dan banyak digemari oleh investor. Emas merupakan salah satu logam mulai yang bernilai tinggi.

Pada hakikatnya investasi merupakan penanaman sejumlah dana yang dilakukan pada saat ini dengan harapan dapat memperoleh keuntungan di masa akan datang (Halim, 2005). Ada dua sisi yang selalu dimiliki dalam berinvestasi yaitu sisi return dan risiko, serta hukum yang berlaku dalam berinvestasi adalah semakin tinggi return yang ditawarkan maka akan semakin tinggi juga risiko yang harus ditanggung oleh investor tersebut (Tendelilin, 2001).

Dengant minat para investor yang cukup tinggi tersebut, maka suatu estimasi atau ramalan harga di masa mendatang perlu di observasi dengan alat prediksi yang efektif. Peramalan harga emas merupakan salah satu cara untuk memprediksi atau memperkirakan harga emas dimasa yang akan datang berdasarkan data di masa lalu yang dapat digunakan sebagai alat untuk berinvestasi. Peramalan dibutuhkan karena dunia bisnis berhadapan dengan ketidakpastian di masa depan dengan menentukan model alat prediksi yang efektif 
yang akhirnya dapat meningkatkan jumlah investor dan para investor tidak ragu dalam melakukan investasi emas.

Selain itu, harga emas yang selalu mengalami perubahan karena kurs dollar yang terus bergerak naik maupun turun membuat nilai mata uang rupiah menjadi ikut tidak stabil juga. Akibatnya berdampak pada harga jual maupun harga beli emas di pasar yang ikut berubah-ubah. Begitu juga dengan harga emas dunia yang ikut melambung tinggi akibat kurs dollar yang tidak stabil. Salah satu perusahaan yang bergerak dalam bidang pertambangan yang ikut terkena dampak dari nilai tukar rupiah yang tidak stabil yaitu PT. Antam (Persero) Tbk. Perusahaan tersebut memproduksi emas dan perak. Akibatnya harga emas pada Logam Mulia mengikuti harga emas dunia yang setiap harinya dapat berubah-ubah.

\section{B. KAJIAN PUSTAKA}

Berbagai penelitian yang membahas tentang emas telah dilakukan, mengingat emas merupakan salah satu instrumen investasi tertua sepanjang sejarah manusia. Sejak zaman dahulu, emas sudah menjadi alat penyimpanan kekayaan yang teruji dalam kurun waktu yang cukup lama. Para investor sampai saat ini masih menyakini kekuatan emas dalam menghadapi gejolak ketidakstabilan fundamental perekonomian suatu negara. Namun, belum banyak penelitian yang menganalisis tentang investasi emas dan penerapan model estimasi yang efektif.

Sebuah penelitian empiris yang dilakukan Anita (2015) mengenai komparasi investasi logam mulia emas dengan saham perusahaan pertambangan menemukan bahwa return dari investasi logam mulia emas tidak memiliki perbedaan yang berarti dengan return investasi saham perusahaan pertambangan.

Berdasarkan hasil analisis model estimasi VAR yang dilakukan Wahyuni (2014) menunjukkan bahwa dalam jangka pendek return emas tidak berpengaruh terhadap return pasar saham. Ini berarti, investasi emas lebih baik atau lebih menguntungkan daripada investasi saham pada masa terjadinya inflasi. Hasil ini menunjukkan bahwa emas memiliki keunggulan untuk diversifikasi dan juga sebagai tempat yang aman bagi investor dan hedge untuk saham.

Sebuah kajian yang dilakukan Nilawati (2008) mengenai analisis peramalan penjualan emas dan perak PT. Aneka Tambang unit bisnis pengolahan dan pemurnian logam mulia sebagai acuan dalam perencanaan strategi pemasaran diketahui bahwa selama periode 2003 - 2007 penjualan ekspor emas dapat mencapai jumlah 404,96 $\mathrm{Kg}$ setiap bulannya (dengan selang peramalan sebesar -231,741 sampai dengan 1.041,66). Peramalan penjualan domestik emas mencapai jumlah $117,919 \mathrm{Kg}$ setiap bulannya (dengan selang peramalan sebesar -145,105 sampai dengan 380,943). Dapat dikatakan bahwa penjualan logam mulia emas cenderung mengalami peningkatan yang artinya minat investor terhadap emas masih cukup tinggi.

Sebuah penelitian kuantitatif yang dilakukan oleh Rasella (2012), menemukan bahwa hasil penjualan dengan menggunakan metode least square terjadi peningkatan penjualan pada setiap kuartal untuk kedua jenis produk yaitu ballpoint tinta fine dan ballpoint tinta gel, namun kenaikan penjualan tidak terlalu signifikan. Sedangkan pada metode indeks musim untuk produk ballpoint tinta fine terjadi kenaikan penjualan pada kuartal 2, mengalami penurunan pada kuartal 
3 dan kembali meningkat kembali pada kuartal 4. Sedangkan untuk produk ballpoint tinta gel terjadi hal yang sama namun penurunan penjualan pada kuartal 3 cukup signifikan dibanding dengan kuartal 2 dan kemudian mengalami peningkatan kembali pada kuartal 4.

Investasi hadir dengan tujuan umum untuk menciptakan uang serta meningkatkan nilai uang dan juga kekayaan untuk masa sekarang ataupun masa mendatang. Terdapat banyak instrumen bagi investor dalam menginvestasikan dana mereka. Emas saat ini merupakan pilihan investasi dengan kategori aman karena menawarkan return keuangan yang cepat dan mudah kepada investor dan juga emas merupakan investasi yang cukup terjangkau, hanya saja kurang memberikan return yang kompetitif. Investor yang menanamkan dananya dalam bentuk emas berarti mereka telah berinvestasi dalam aset dan ada manfaat yang signifikan dalam investasi emas.

Dari penelitian sebelumnya telah banyak yang membahas mengenai investasi emas yang mana investasi ini cukup menjanjikan untuk jangka panjang sehingga angka penjualan emas tiap tahunnya terus mengalami peningkatan dikarenakan tingginya permintaan akan emas. Namun belum banyak ditemui penelitian yang membahas secara empiris mengenai penerapan model estimasi atau ramalan yang manakah, yang efektif dan dapat digunakan dalam memprediksi harga emas pada masa yang akan datang. Untuk itu, penelitian ini mencoba untuk menganalisis beberapa pertanyaan penting berkaitan dengan penerapan model estimasi atau ramalan yang efektif dalam meramal harga emas di masa yang akan datang pada PT. Aneka Tambang (ANTAM). Pembahasan dalam penelitian ini akan fokus pada analisis penerapan model estimasi yang efektif dalam penjualan emas dan mengidentifikasi model-model alat analisis statistik yang digunakan sebagai alat prediksi.

Dari beberapa penjelasan diatas dapat disimpulkan peramalan adalah sebuah permintaan barang atau dan jasa untuk masa mendatang melalui data di masa lalu. Manajemen produksi menggunakan hasil peramalan untukmenyediakan stok barang sesuai dengan yang telah diramalkan.

\section{METODE PENELITIAN}

Teknik pengumpulan data dalam penelitian ini menggunakan library research yang bertujuan untuk mendapatkan data sekunder. Data sekunder adalah data yang diperoleh atau dikumpulkan peneliti dari berbagai sumber leaflet, laporan-laporan, catatan-catatan, buku-buku, koran dan sebagainya.

Berdasarkan penguraian sebelumnya, maka dapat disimpulkan bahwa Investasi merupakan suatu aktivitas, berupa penundaan konsumsi di masa sekarang dalam jumlah tertentu dan selama periode waktu tertentu pada suatu asset yang efisien oleh investor, dengan tujuan memperoleh keuntungan di masa yang akan datang pada tingkat tertentu sesuai dengan yang diharapkan, tentunya yang lebih baik dari pada mengkonsumsi di masa sekarang. Menurut Fahmi dan Hadi (2009) dalam bukunya yang berjudul Teori Portofolio dan Analisis Investasi dalam aktivitasnya investasi pada umumnya dikenal ada dua bentuk, yaitu: real investment dan financial investment. Perbedaan antara investasi pada real 
investment dan financial investment adalah tingkat likuiditas dari kedua investasi tersebut. Investasi pada real investment relatif lebih sulit untuk dicairkan karena terbentur pada komitmen jangka panjang antara investor dengan perusahaan. Sementara investasi pada financial investment lebih mudah dicairkan karena dapat diperjualbelikan tanpa terikat waktu.

Prasetya dan Lukiastuti (2009) menjelaskan bahwa peramalan merupakan suatu usaha untuk meramalkan keadaan masa mendatang melalui pengujian keadaan di masa lalu. Esensi peramalan adalah perkiraan peristiwa-peristiwa diwaktu yang akan datang atas dasar pola-pola di waktu yang lalu, dan penggunaan kebijakan terhadap proyeksi-proyeksi dengan pola-pola di waktu yang lalu. Adapun, Santoso (2009) mendefinisikan forecasting sebagai perkiraan munculnya sebuah kejadian di masa depan, berdasarkan data yang ada di masa lampau, berbasis pada metode ilmiah (ilmu dan teknologi) serta dilakukan dengan sistematis.

Dari beberapa penjelasan diatas dapat disimpulkan peramalan adalah sebuah permintaan barang atau dan jasa untuk masa mendatang melalui data di masa lalu. Manajemen produksi menggunakan hasil peramalan untukmenyediakan stok barang sesuai dengan yang telah diramalkan.

Dari uraian di atas maka berdasarkan tingkat ekplanasinya termasuk predictive research (Supranto, 2007), yakni model-model research untuk memperkirakan fenomena mendatang. Metode kuantitatif memerlukan data historik atau empiris dan variabel yang digunakan harus mempunyai satuan ukur atau dapat diukur, metode ini beranggapan bahwa pola masa lalu akan berulang. Metode kuantitatif didasarkan pada pemanipulasian atas data yang tersedia secara memadai dan tanpa intuisi ataupun penilaian subjektif dari orang yang melakukan peramalan.

Dalam penelitian ini yang diamati adalah variabel penjualan (PJN) secara deskriptif kuantitatif dengan menggunakan historical time series per kuartal dari tahun 2012 kuartal 1 sampai 2016 kuartal 4. Bila data tidak tersedia diambil nilai rata-rata pada kuartal tersebut. Dengan menerapkan model metode ordinary least square, lalu diteruskan dengan metode semi average, rate of growth, smooth moving average, naive method, dan metode dekomposisi dengan menggunakan software Microsoft Office Excel versi 2010 sebagai alat statistik yang digunakan untuk menguji metode mana yang lebih efektif digunakan sebagai alat peramalan kegiatan penjualan emas.

\section{HASIL DAN PEMBAHASAN}

Berdasarkan karakteristik masalah yang akan diteliti, penelitian ini diklasifikasikan ke dalam penelitian metode kuantitatif dan uji SPSS yang bertujuan untuk mengidentifikasi model-model alat analisis statistik yang digunakan sebagai alat prediksi investasi emas. Untuk mengetahui hasil peramalan dan model estimasi yang mana mempunyai Mean Square Error yang terkecil dari tahun 2012 Q1 - 2016 Q4 dibahas sebagai berikut: 


\section{Metode Ordinary Least Square}

Model ini baik digunakan bila diagram pancarnya menunjukkan pola perubahan yang hampir mendekati garis lurus.

Tabel 1.1

Model Ordinary Least Square (OLS)

\begin{tabular}{|c|c|c|c|c|c|c|c|c|}
\hline Tahun & Kuartal & $\mathbf{Y t}$ & $\mathbf{x}$ & $\mathbf{x y}$ & $\mathbf{x}^{\mathbf{2}}$ & $\hat{\mathbf{y}}$ & $\mathbf{( \mathbf { y } - \hat { \mathbf { y } } )}$ & $(\mathbf{y}-\hat{\mathbf{y}})^{\mathbf{2}}$ \\
\hline \multirow{4}{*}{2012} & I & & & & & & & \\
\cline { 2 - 9 } & II & 1349,57 & -9 & $-12146,13$ & 81 & 1607,95 & $-258,38$ & 66760,2244 \\
\cline { 2 - 9 } & III & 906,77 & -8 & $-7254,16$ & 64 & 1611,485 & $-704,715$ & 496623,2312 \\
\cline { 2 - 9 } & IV & 1584,28 & -7 & $-11089,96$ & 49 & 1615,024 & $-30,744$ & 945,193536 \\
\hline \multirow{4}{*}{2013} & I & 2509,43 & -6 & $-15056,58$ & 36 & 1618,513 & 890,917 & 793733,1009 \\
\cline { 2 - 9 } & II & 2083,82 & -5 & $-10419,1$ & 25 & 1622,102 & 461,718 & 213183,5115 \\
\cline { 2 - 9 } & III & 1641,91 & -4 & $-6567,64$ & 16 & 1625,641 & 16,269 & 264,680361 \\
\cline { 2 - 9 } & IV & 1155,57 & -3 & $-3466,71$ & 9 & 1629,16 & $-473,59$ & 224287,4881 \\
\hline \multirow{4}{*}{2014} & I & 1622,96 & -2 & $-3245,92$ & 4 & 1632,719 & $-9,759$ & 95,238081 \\
\cline { 2 - 9 } & II & 1098,58 & -1 & $-1098,58$ & 1 & 1636,258 & $-537,678$ & 289097,6317 \\
\cline { 2 - 9 } & III & 1392,53 & 0 & 0 & 0 & 1639,797 & $-247,267$ & 61140,96929 \\
\cline { 2 - 9 } & IV & 1967,4 & 1 & 1967,4 & 1 & 1643,336 & 324,064 & 105017,4761 \\
\hline \multirow{4}{*}{2015} & I & 2106,36 & 2 & 4212,72 & 4 & 1646,825 & 459,535 & 211172,4162 \\
\cline { 2 - 9 } & II & 1023,74 & 3 & 3071,22 & 9 & 1650,414 & $-626,674$ & 392720,3023 \\
\cline { 2 - 9 } & III & 1111,13 & 4 & 4444,52 & 16 & 1653,953 & $-542,823$ & 294656,8093 \\
\cline { 2 - 9 } & IV & 2430,44 & 5 & 12152,2 & 25 & 1657,492 & 772,948 & 597448,6107 \\
\hline \multirow{5}{*}{} & I & 2387,85 & 6 & 14327,1 & 36 & 1661,031 & 726,819 & 528265,8588 \\
\cline { 2 - 8 } & II & 1407,62 & 7 & 9853,34 & 49 & 1664,57 & $-256,95$ & 66023,3025 \\
\cline { 2 - 8 } & III & 1617,54 & 8 & 12940,32 & 64 & 1668,109 & $-50,569$ & 2557,223761 \\
\cline { 2 - 8 } & IV & 1749,65 & 9 & 15746,85 & 81 & 1671,646 & 78,004 & 6084,624016 \\
\hline
\end{tabular}

$$
\begin{aligned}
M S E & =\frac{\sum(y-\hat{y})^{2}}{n-1} \\
& =\frac{4350077,89}{18} \\
& =\mathbf{2 4 1 6 7 1}
\end{aligned}
$$

Maka estimasi di tahun 2017 dapat ditunjukan sebagai berikut:

\begin{tabular}{|c|c|c|c|}
\hline Tahun & Triwulan & $\mathbf{x}$ & $\hat{\mathbf{y}}$ \\
\hline \multirow{3}{*}{2017} & I & 10 & 1675.187 \\
\cline { 2 - 4 } & II & 11 & 1678.726 \\
\cline { 2 - 4 } & III & 12 & 1682.265 \\
\cline { 2 - 4 } & IV & 13 & 1685.804 \\
\hline \multicolumn{2}{|c|}{ Total } & 6721.982 \\
\hline
\end{tabular}

\section{Metode Semi Average}

Salah satu metode untuk melihat trend dari data selain metode tangan bebas, metode least square average adalah dengan metode semi average, hal ini bisa diterapkan bila variasi sikli yang terdapat diatas dan dibawah garis trend kurang lebih sama. 
Tabel 1.2

Model Semi Average

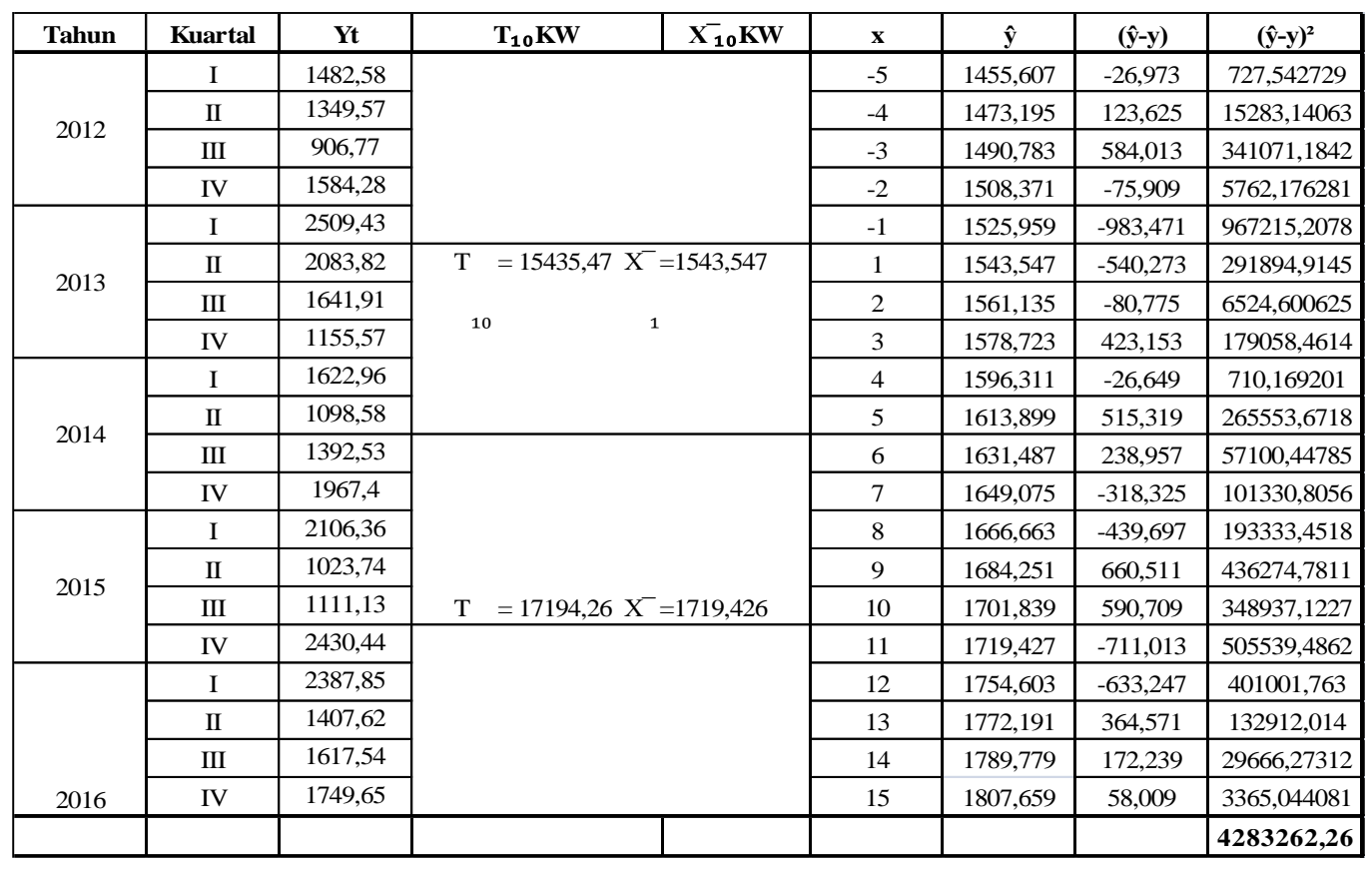

$$
\begin{aligned}
M S E & =\frac{\sum(y-\hat{y})^{2}}{n-1} \\
& =\frac{4283262,26}{20} \\
& =\mathbf{2 1 4 1 6 3 , 1 1}
\end{aligned}
$$

Estimasi tahun 2017

\begin{tabular}{|c|c|c|c|}
\hline Tahun & Kuartal & $\widehat{\boldsymbol{y}}$ & $\widehat{\boldsymbol{y}}_{\mathbf{2 0 1 7}}$ \\
\hline \multirow{3}{*}{2017} & I & $1543,547+17,588(11)$ & 1737,015 \\
\cline { 2 - 4 } & II & $1543,547+17,588(12)$ & 1754,603 \\
\cline { 2 - 4 } & III & $1543,547+17,588(13)$ & 1772,191 \\
\cline { 2 - 4 } & IV & $1543,547+17,588(14)$ & 1789,779 \\
\hline \multicolumn{2}{|c|}{ Total } & 8053,588 \\
\hline
\end{tabular}

\section{Metode Rate of Growth}

Metode rate of growth merupakan pengembangan dari salah satu pengukuran nilai central yakni rata-rata ukur disamping rata-rata hitung, rata-rata harmonis dan lainnya. Sebenarnya rata-rata ukur lebih akurat dibandingkan ratarata hitung. Namun, perhitungannya kadang kala relatif lebih sulit. 
Tabel 1.3

Model Rate of Growth

\begin{tabular}{|c|c|c|c|c|c|c|}
\hline Tahun & Kuartal & $\mathbf{Y t}$ & & $\hat{\mathbf{y}}$ & $(y-\hat{y})$ & $(y-\hat{y})^{2}$ \\
\hline \multirow{4}{*}{2012} & $\mathrm{I}$ & 1482,58 & $\mathrm{P}_{0}=1482,58$ & 1482,58 & 0 & 0 \\
\hline & II & 1349,57 & & 1510,141 & $-160,571$ & 25783,04604 \\
\hline & III & 906,77 & & 1538,215 & $-631,445$ & 398722,788 \\
\hline & IV & 1584,28 & & 1566,81 & 17,47 & 305,2009 \\
\hline \multirow{4}{*}{2013} & I & 2509,43 & & 1595,937 & 913,493 & 834469,461 \\
\hline & II & 2083,82 & & 1625,606 & 458,214 & 209960,0698 \\
\hline & III & 1641,91 & & 1655,826 & $-13,916$ & 193,655056 \\
\hline & IV & 1155,57 & & 1686,607 & $-531,037$ & 282000,2954 \\
\hline \multirow{4}{*}{2014} & I & 1622,96 & & 1717,961 & $-95,001$ & 9025,190001 \\
\hline & II & 1098,58 & & 1749,898 & $-651,318$ & 424215,1371 \\
\hline & III & 1392,53 & & 1782,429 & $-389,899$ & 152021,2302 \\
\hline & IV & 1967,4 & & 1815,564 & 151,836 & 23054,1709 \\
\hline \multirow{4}{*}{2015} & $\mathrm{I}$ & 2106,36 & & 1849,316 & 257,044 & 66071,61794 \\
\hline & II & 1023,74 & & 1883,694 & $-859,954$ & 739520,8821 \\
\hline & III & 1111,13 & & 1918,712 & $-807,582$ & 652188,6867 \\
\hline & IV & 2430,44 & & 1954,381 & 476,059 & 226632,1715 \\
\hline \multirow{5}{*}{2016} & $\mathrm{I}$ & 2387,85 & & 1990,713 & 397,137 & 157717,7968 \\
\hline & II & 1407,62 & & 2027,72 & $-620,1$ & 384524,01 \\
\hline & III & 1617,54 & & 2065,416 & $-447,876$ & 200592,9114 \\
\hline & IV & 1749,65 & $\operatorname{Pn}=1749,65$ & 2103,812 & $-354,162$ & 125430,7222 \\
\hline & & & & & & 4912429,04 \\
\hline
\end{tabular}

$P_{n}=P_{0}(1+r)^{n-1}$

$1749,65=1482,58(1+r)^{19}$

$\log 1749,65=\log 1482,58+19 \log (1+r)$

$19 \log (1+r)=\log 1482,58+\log 1749,65$

$\log (1+r)=3,2430-3,1710$

$$
\begin{aligned}
& \mathrm{r}=0,008 / 1,859 \% \\
M S E & =\frac{\sum(y-\hat{y})^{2}}{n-1} \\
= & \frac{4912429,04}{18} \\
= & \mathbf{2 6 6 4 1 4 , 4 0 7}
\end{aligned}
$$

Maka estimasi tahun 2017:

\begin{tabular}{|c|c|c|c|}
\hline Tahun & Kuartal & $\mathbf{n - 1}$ & $\widehat{\boldsymbol{y}}$ \\
\hline \multirow{4}{*}{2017} & I & 20 & 2142,922 \\
\cline { 2 - 4 } & II & 21 & 2182,759 \\
\cline { 2 - 4 } & III & 22 & 2223,336 \\
\cline { 2 - 4 } & IV & 23 & 2264,668 \\
\hline \multicolumn{2}{|c|}{ Total } & 8813,685 \\
\hline
\end{tabular}


Tabel 1.5

Model Naive

\begin{tabular}{|c|c|c|c|c|c|}
\hline Tahun & Kuartal & $\mathbf{Y t}$ & $\hat{\mathbf{y}}$ & $e_{i}$ & $e_{i}^{2}$ \\
\hline \multirow{4}{*}{2012} & I & 1482,58 & & & \\
\hline & II & 1349,57 & 1482,58 & $-133,01$ & 17691,6601 \\
\hline & III & 906,77 & 1349,57 & $-442,8$ & 196071,84 \\
\hline & IV & 1584,28 & 906,77 & 677,51 & 459019,8001 \\
\hline \multirow{4}{*}{2013} & $\mathrm{I}$ & 2509,43 & 1584,28 & 925,15 & 855902,5225 \\
\hline & II & 2083,82 & 2509,43 & $-425,61$ & 181143,8721 \\
\hline & III & 1641,91 & 2083,82 & $-441,91$ & 195284,4481 \\
\hline & IV & 1155,57 & 1641,91 & $-486,34$ & 236526,5956 \\
\hline \multirow{4}{*}{2014} & $\mathrm{I}$ & 1622,96 & 1155,57 & 467,39 & 218453,4121 \\
\hline & II & 1098,58 & 1622,96 & $-524,38$ & 274974,3844 \\
\hline & III & 1392,53 & 1098,58 & 293,95 & 86406,6025 \\
\hline & IV & 1967,4 & 1392,53 & 574,87 & 330475,5169 \\
\hline \multirow{4}{*}{2015} & $\mathrm{I}$ & 2106,36 & 1967,4 & 138,96 & 19309,8816 \\
\hline & II & 1023,74 & 2106,36 & $-1082,62$ & 1172066,064 \\
\hline & III & 1111,13 & 1023,74 & 87,39 & 7637,0121 \\
\hline & IV & 2430,44 & 1111,13 & 1319,31 & 1740578,876 \\
\hline \multirow[b]{4}{*}{2016} & $\mathrm{I}$ & 2387,85 & 2430,44 & $-42,59$ & 1813,9081 \\
\hline & II & 1407,62 & 2387,85 & $-980,23$ & 960850,8529 \\
\hline & III & 1617,54 & 1407,62 & 209,92 & 44066,4064 \\
\hline & IV & 1749,65 & 1617,54 & 132,11 & 17453,0521 \\
\hline 2017 & $\mathbf{I}$ & & 1749,65 & & 7015726,708 \\
\hline
\end{tabular}

$M S E=\frac{\sum_{i=1}^{n} e_{i}^{2}}{n-1}$

$$
\begin{aligned}
& =\frac{7015726,708}{18} \\
& =\mathbf{3 8 9 7 6 2 , 6 0}
\end{aligned}
$$

\section{Metode Dekomposisi}

Metode dekomposisi relatif lebih rumit karena menggabungkan variasi musim dari data yang diamati, dengan kecenderungan bentuk regresinya atau dengan kata lain peramalan regresi disesuaikan dengan kecenderungan index musim dari data-data yang lalu. 
Tabel 1.6

Model Dekomposisi

\begin{tabular}{|c|c|c|c|c|c|c|}
\hline Tahun & Kuartal & $\mathbf{Y t}$ & Jml 4kw & Jml 8kw & Rata2 8kw & S\&I \\
\hline \multirow{6}{*}{2012} & I & 1482,58 & & & & \\
\hline & II & 1349,57 & & & & \\
\hline & & & 5323,2 & & & \\
\hline & III & 906,77 & & 11673,25 & 1459,156 & 0,6214 \\
\hline & & & 6350,05 & & & \\
\hline & IV & 1584,28 & & 13434,35 & 1679,294 & 0,9434 \\
\hline & & & 7084,3 & & & \\
\hline \multirow{7}{*}{2013} & I & 2509,43 & & 14903,74 & 1862,968 & 1,3470 \\
\hline & & & 7819,44 & & & \\
\hline & II & 2083,82 & & 15210,17 & 1901,271 & 1,0960 \\
\hline & & & 7390,73 & & & \\
\hline & III & 1641,91 & & 13894,99 & 1736,874 & 0,9453 \\
\hline & & & 6504,26 & & & \\
\hline & IV & 1155,57 & & 12023,28 & 1502,910 & 0,7689 \\
\hline & & & 5519,02 & & & \\
\hline \multirow{7}{*}{2014} & I & 1622,96 & & 10788,66 & 1348,583 & 1,2035 \\
\hline & & & 5269,64 & & & \\
\hline & II & 1098,58 & & 11351,11 & 1418,889 & 0,7743 \\
\hline & & & 6081,47 & & & \\
\hline & III & 1392,53 & & 12646,34 & 1580,793 & 0,8809 \\
\hline & & & 6564,87 & & & \\
\hline & IV & 1967,4 & & 13054,9 & 1631,863 & 1,2056 \\
\hline & & & 6490,03 & & & \\
\hline \multirow{7}{*}{2015} & $\mathrm{I}$ & 2106,36 & & 12980,06 & 1622,508 & 1,2982 \\
\hline & & & 6490,03 & & & \\
\hline & II & 1023,74 & & 12698,66 & 1587,333 & 0,6449 \\
\hline & & & 6208,63 & & & \\
\hline & III & 1111,13 & & 12880,3 & 1610,038 & 0,6901 \\
\hline & & & 6671,67 & & & \\
\hline & IV & 2430,44 & & 13624,83 & 1703,104 & 1,4271 \\
\hline & & & 6953,16 & & & \\
\hline \multirow[b]{7}{*}{2016} & $\mathrm{I}$ & 2387,85 & & 14290,2 & 1786,275 & 1,3368 \\
\hline & & & 7337,04 & & & \\
\hline & II & 1407,62 & & 15180,49 & 1897,561 & 0,7418 \\
\hline & & & 7843,45 & & & \\
\hline & III & 1617,54 & & 15006,11 & 1875,764 & 0,8623 \\
\hline & & & 7162,66 & & & \\
\hline & IV & 1749,65 & & 7162,66 & 895,333 & 1,9542 \\
\hline
\end{tabular}


Tabel 1.7

Index Musim Dekomposisi (IMD)

\begin{tabular}{|c|c|c|c|c|c|c|c|}
\hline KW & $\mathbf{2 0 1 2}$ & $\mathbf{2 0 1 3}$ & $\mathbf{2 0 1 4}$ & $\mathbf{2 0 1 5}$ & $\mathbf{2 0 1 6}$ & Median & IMD \\
\hline I & & 1,347 & 1,2034 & 1,327 & 1,2584 & 1,2927 & 1,3271 \\
\hline II & & 1,096 & 0,7743 & 0,6358 & 0,7504 & 0,7624 & 0,7827 \\
\hline III & 0,6214 & 0,9453 & 0,8809 & 0,6524 & - & 0,7667 & 0,7871 \\
\hline IV & 0,9434 & 0,7689 & 1,2056 & 1,3606 & - & 1,0745 & 1,1031 \\
\hline & & & & & & 3,8963 & 4,00 \\
\hline
\end{tabular}

Maka ramalan tahun 2017 tercatat sebagai berikut:

\begin{tabular}{|c|c|c|c|}
\hline Tahun & Kuartal & $\widehat{\boldsymbol{y}}$ & $\widehat{\boldsymbol{y}}_{\mathbf{2 0 1 7}}$ \\
\hline \multirow{3}{*}{2017} & I & $1529,959+15,816(21)$ & 1862,095 \\
\cline { 2 - 4 } & II & $1529,959+15,816(22)$ & 1877,911 \\
\cline { 2 - 4 } & III & $1529,959+15,816(23)$ & 1893,727 \\
\cline { 2 - 4 } & IV & $1529,959+15,816(24)$ & 1909,543 \\
\hline \multicolumn{2}{|r|}{ Total } & 7543,276 \\
\hline
\end{tabular}

Tabel 1.8

Model Dekomposisi 2

\begin{tabular}{|c|c|c|c|c|c|c|c|c|c|c|}
\hline Tahun & Kuartal & Yt & $\mathbf{S}$ & $\mathrm{yt} / \mathrm{s}$ & $\mathbf{t}$ & t2 & (t) $(\mathrm{yt} / \mathrm{s})$ & $\hat{\mathbf{y}}$ & $(y-\hat{y})$ & $(y-\hat{y})^{2}$ \\
\hline \multirow{4}{*}{2012} & I & 1482,58 & 1,2927 & 1146,8864 & 1 & 1 & 1146,88636 & 1545,775 & $-63,195$ & 3993,608025 \\
\hline & II & 1349,57 & 0,7624 & 1770,16 & 2 & 4 & 3540,32004 & 1561,591 & $-212,021$ & 44952,90444 \\
\hline & III & 906,77 & 0,7667 & 1182,6921 & 3 & 9 & 3548,07617 & 1577,407 & $-670,637$ & 449753,9858 \\
\hline & IV & 1584,28 & 1,0745 & 1474,4346 & 4 & 16 & 5897,73848 & 1593,223 & $-8,943$ & 79,977249 \\
\hline \multirow{4}{*}{2013} & I & 2509,43 & 1,2927 & 1941,2315 & 5 & 25 & 9706,15765 & 1609,039 & 900,391 & 810703,9529 \\
\hline & II & 2083,82 & 0,7624 & 2733,2371 & 6 & 36 & 16399,4229 & 1624,855 & 458,965 & 210648,8712 \\
\hline & III & 1641,91 & 0,7667 & 2141,5286 & 7 & 49 & 14990,7004 & 1640,671 & 1,239 & 1,535121 \\
\hline & IV & 1155,57 & 1,0745 & 1075,449 & 8 & 64 & 8603,59237 & 1656,487 & $-500,917$ & 250917,8409 \\
\hline \multirow{4}{*}{2014} & $\mathrm{I}$ & 1622,96 & 1,2927 & 1255,4808 & 9 & 81 & 11299,327 & 1672,303 & $-49,343$ & 2434,731649 \\
\hline & II & 1098,58 & 0,7624 & 1440,9496 & 10 & 100 & 14409,4963 & 1688,119 & $-589,539$ & 347556,2325 \\
\hline & III & 1392,53 & 0,7667 & 1816,2645 & 11 & 121 & 19978,9096 & 1703,935 & $-311,405$ & 96973,07403 \\
\hline & IV & 1967,4 & 1,0745 & 1830,9912 & 12 & 144 & 21971,8939 & 1719,751 & 247,649 & 61330,0272 \\
\hline \multirow{4}{*}{2015} & I & 2106,36 & 1,2927 & 1629,4268 & 13 & 169 & 21182,5482 & 1735,567 & 370,793 & 137487,4488 \\
\hline & II & 1023,74 & 0,7624 & 1342,7859 & 14 & 196 & 18799,0031 & 1751,383 & $-727,643$ & 529464,3354 \\
\hline & III & 1111,13 & 0,7667 & 1449,237 & 15 & 225 & 21738,5548 & 1767,199 & $-656,069$ & 430426,5328 \\
\hline & IV & 2430,44 & 1,0745 & 2261,9265 & 16 & 256 & 36190,8236 & 1783,015 & 647,425 & 419159,1306 \\
\hline \multirow{5}{*}{2016} & $\mathrm{I}$ & 2387,85 & 1,2927 & 1847,1803 & 17 & 289 & 31402,0654 & 1798,831 & 589,019 & 346943,3824 \\
\hline & II & 1407,62 & 0,7624 & 1846,3012 & 18 & 324 & 33233,4208 & 1814,641 & $-407,021$ & 165666,0944 \\
\hline & III & 1617,54 & 0,7667 & 2109,7431 & 19 & 361 & 40085,118 & 1830,463 & $-212,923$ & 45336,20393 \\
\hline & IV & 1749,65 & 1,0745 & 1628,3388 & 20 & 400 & 32566,7752 & 1846,279 & $-96,629$ & 9337,163641 \\
\hline & & & & 33924,24 & 210 & 2870 & 366690,8 & & & 4363167,03 \\
\hline
\end{tabular}

$$
\begin{aligned}
M S E & =\frac{\sum(y-\hat{y})^{2}}{n-1} \\
& =\frac{4363167,03}{19} \\
& =229640,37
\end{aligned}
$$

Setelah dilakukan penghitungan dengan cukup teliti, peneliti melakukan pembandingan keenam model tersebut sebagai berikut: 
Tabel 1.9

Rekapitulasi Hasil Estimasi Dengan Keenam Model

\begin{tabular}{|c|c|c|c|c|c|c|}
\hline \multirow{2}{*}{ Metode } & \multicolumn{4}{|c|}{ Estimasi 2017} & \multirow{2}{*}{ Total } & \multirow{2}{*}{ MSE } \\
\hline & I & II & III & IV & & \\
\hline OLS & 1675,167 & 1678,726 & 1682,265 & 1685,804 & 6721,962 & 197588,462 \\
\hline Semi Average & 1737,015 & 1754,603 & 1772,191 & 1789,779 & 7053,588 & 214140,363 \\
\hline Rate of Growth & 2142,922 & 2182,759 & 2223,336 & 2264,668 & 8813,685 & 266414,407 \\
\hline SMA & 1108,27 & - & - & - & - & 460609 \\
\hline Naive & 1749,65 & - & - & - & - & 389738,47 \\
\hline Dekomposisi & 1862,095 & 1877,911 & 1893,727 & 1909,543 & 7543,276 & 229682,082 \\
\hline
\end{tabular}

Dari tabel diatas terlihat bahwa metode SMA dan Naive mempunyai kelemahan yakni memprediksi hanya waktu $\hat{y}_{t+1}$ saja sehingga tidak bisa digunakan untuk estimasi kuartal II, III, dan IV serta MSE kedua model tersebut juga cukup besar dibanding model yang lainnya.

Metode rate of growth juga tidak bagus untuk estimasi karena hasil estimasi yang dihasilkan oleh model tersebut sangat jauh berbeda dengan model yang lainnya serta MSE model yang dihasilkan oleh metode rate of growth relatif besar. Metode dekomposisi juga disamping perhitungannya cukup rumit yang mana metode ini juga harus memperhatikan Index Musim ditambah lagi hasil MSE metode ini jauh diatas OLS dan semi average.

Dengan demikian, dari keenam model yang diterapkan dalam penelitian ini terlihat bahwa MSE yang lebih rendah diperoleh pada metode Ordinary Least Square dan metode Semi Average. Diantara kedua model ini juga dapat dilihat coefisien variasi dari masing-masing rata-rata keenam model tersebut.

$C V=\frac{s}{\bar{x}} \times 100 \%=\frac{\sqrt{M S E}}{\bar{x}_{2017}}$

\section{Ordinary Least Square Method}

$C V=\frac{\sqrt{197588,462}}{1680,49} \times 100 \%=26,45 \%$

\section{Semi Average Method}

$C V=\frac{\sqrt{214140,363}}{1763,397} \times 100 \%=26,24 \%$

Dari perhitungan diatas dapat dilihat bahwa hasil dari kedua metode tersebut hampir sama atau selisihnya sedikit sekali, maka dalam estimasi model semi average relatif lebih baik dibanding model-model yang diterapkan dalam penelitian ini. 


\section{E. SIMPULAN}

Berdasarkan hasil peramalan penjualan untuk emas batangan pada PT Antam (Persero) Tbk dengan menggunakan 6 metode trend yang telah diterapkan dalam penelitian ini, diperoleh bahwa dengan metode ordinary least square diperoleh ramalan penjualan emas di tahun 2017 sebesar 6721,982 kg dengan Mean Square Error sebesar 241671, sedangkan dari hasil perhitungan dengan menggunakan metode semi average diperoleh ramalan penjualan emas pada tahun 2017 sebesar 8053,588 kg dengan MSE sebesar 214163,11. Lebih lanjut, perhitungan dengan menggunakan metode rate of growth diperoleh total estimasi penjualan tahun 2017 sebesar 8803,685 kg dengan MSE sebesar 266414,40.

Adapun dari hasil perhitungan dengan menggunakan metode Smooth Moving Average (SMA) diperoleh estimasi kuartal I sebesar 1108,27 kg dengan MSE 450923,68. Metode ini memiliki kelemahan karena hanya meramalkan satu periode mendatang. Sama halnya dengan metode naive yang juga hanya terbatas pada satu periode mendatang karena data yang diobservasi adalah data kuartal maka hanya satu kuartal kedepan yakni 1108,27 kg dengan nilai MSE cukup tinggi yaitu sebesar 389962,60. Dalam metode dekomposisi yang relatif lebih rumit karena metode ini menggabungkan index variasi musim dengan regresi ternyata MSE diperoleh relatif lebih besardari metode Ordinary Least Square dan juga metode Semi Average.

Dengan demikian terlihat bahwa yang memiliki nilai MSE lebih rendah adalah metode Ordinary Least square (OLS) dan juga metode Semi Average. Dari kedua metode tersebut dapat dilihat bahwa metode semi average memiliki angka coefisien regresi yang cukup baik dan angka tersebut dapat digunakan untuk

\section{DAFTAR PUSTAKA}

Anita. (2015). Analisis Komparasi Investasi Logam Mulia Emas Dengan Saham Perusahaan Pertambangan di Bursa Efek Indonesia 2010-2014. Jurnal Bisnis dan Manajemen, 10.

Fahmi, I., \& Hadi, Y. L. (2009). Teori Portofolio dan Analisis Investasi. Bandung: Alfabeta.

Halim, A. (2005). Analisis Investasi. Jakarta: Salemba Empat.

Jain, T. R., \& P., K. O. (2007). Economic Concept and Methods. New Delhi: VK. Publication.

Nilawati, M. (2008). Analisis Peramalan Penjualan Emas dan Perak PT. Aneka Tambang, Tbk Unit Bisnis Pengolahan dan Pemurnian Logam Mulia Sebagai Acuan Dalam Perencanaan Strategi Pemasaran. Bogor: Departemen Manajemen, Fakultas Ekonomi dan Manajemen, IPB. 
Prasetya, H., \& Fitri, L. (2009). Manajemen Operasional. Yogyakarta: Media Presindo.

PT. Antam Tbk. (2012-2016). Laporan Kuartal . Jakarta: PT. Antam (Persero) Tbk.

Rasella, V. (2012). Analisis Peramalan Penjualan Ballpoint Standard Pada PT. Jalur Sutramas di Jakarta. Jakarta: Program Studi Manajemen, Fakultas Ekonomi dan Bisnis, Universitas Pancasila.

Santoso, S. (2009). Business Forecasting Metode Peramalan Bisnis Masa Kini Dengan Minitab dan SPSS. Jakarta: PT. Elex Media Komputindo.

Supranto, J. (2007). Metode Riset dan Aplikasi Dalam Pemasaran, Edisi 7. Jakarta: PT. Rineka Cipta.

Tandelilin, E. (2001). Analisis Investasi dan Manajemen Portofolio, Edisi Pertama. Yogyakarta: BPFE UGM.

Wahyuni, A. N. (2014). Analisis Perbandingan Kinerja Investasi Emas dan Investasi Saham Selama Masa Inflasi 1994-2013. Jurnal Bisnis Strategi, 15. 